How to cite this article:

Ya'u, A., Saad, N., \& Mas'ud, A. (2020). Developing a measurement scale for assessing the efficiency of tax administration among oil and gas companies in Nigeria. Malaysian Management Journal, 24(July), 57-76.https://doi.org/10.32890/mmj.24.2020.7602

\title{
DEVELOPING A MEASUREMENT SCALE FOR ASSESSING THE EFFICIENCY OF TAX ADMINISTRATION AMONG OIL AND GAS COMPANIES IN NIGERIA
}

\author{
*ABBA YA'U \\ NATRAH SAAD \\ ABDULSALAM MAS'UD \\ Tunku Puteri Intan Safinaz School of Accountancy \\ Universiti Utara Malaysia \\ *Corresponding author: abbayau1@gmail.com
}

\begin{abstract}
Inefficient tax system causes the government to lose a huge amount of revenue. Tax administrators are primarily responsible for collecting taxes due from taxpayers following the relevant tax laws and regulation in a way that instils confidence on taxpayers through efficient tax administration. This paper aims at validating relevant and reliable measurement scale for assessing the effectiveness of tax administration efficiency in dealing with oil and gas companies operating in the Nigerian oil sector. Hence, an adapted questionnaire comprising four items was administered on 300 local and multinational oil and gas companies in Nigeria. All the items were subjected to evaluations and validations by eight experts' reviewers with cognate experience in oil and gas activities. Evaluation of reliability and validity of the measures of tax administration efficiency was performed through Confirmatory Factor Analysis (CFA) using SPSS version 25 and Smart PLS version 3.8. The results provide evidence that the proposed tax administration efficiency scale attained reliability and validity criteria. Consequently, Policymakers, practitioners and researchers can adapt this scale to assess the effectiveness of tax administration efficiency by companies in different jurisdictions across the globe. This study expands existing literature and
\end{abstract}


contributes new ideas to the subject area. By implication, the validated scale will assist oil and gas producing countries to come up with policies that ensures efficiency in tax administration and increase government revenues.

Keywords: Tax administration efficiency, measurements scale, oil and gas, oil companies.

Received: 5/1/2020 Revised: 22/7/2020 Accepted: 27/7/2020 Published: 30/8/2020

\section{Introduction}

The main key obligation of a tax administration is to harness and pilot the collections of appropriate amounts of taxes due to the government at minimum level of cost to the public. Additionally, other objectives of tax administration are to efficiently collect and manage taxes, implement tax policies as well as encourage investment (Rahman, 2009). Tax administration is considered efficient if the tax administrators are able to increase government revenue while restoring taxpayer's confidence through active and efficient implementation of tax policies (Baurer, 2005). Lack of robust tax policies encourages tax evasion which is described as generally illegal and socially undesirable attitudes (Houston \& Tran, 2001). Taxation system effectiveness is determined by tax administration efficiency in revenue generation (Nyabwengi \& K'Akumu, 2019). Tax administration can be considered efficient if it initiates robust policies to encourage voluntary tax compliance. However, it is obvious that some tax policies are inefficient due to poor tax administration efficiency which invariably discourages voluntary tax compliance.

However, many reasons may lead to tax administration inefficiency. For example, inadequately trained personnel, lack of accountability, lack of transparency, poor record-keeping, lack of autonomy, poor service quality and corruption (Ogbonna, 2011). Other factors that may cause tax administration inefficiency includes lack of accountability, lack of clear administrative strategies and lack of taxpayers' incentives (United Nations, 2000). Developing countries are mostly affected by tax administration inefficiency. For instance, such countries lack good internal control, proper segregation of duties, internal and external oversight and strong code of conduct (Baurer, 2005).

It is obvious that inefficient tax administration exists especially in developing countries which necessitate further investigation because of its importance in increasing government revenues and encouraging taxpayers' compliance. 
Recent empirical studies on tax administration efficiency focuses on its determinants. Other studies focus on the impact of tax administration efficiency on individual taxpayers and on banks due to degeneration of non-performing asset (Abiola \& Asiweh 2012; Alharethi, 2018; Esteller, 2003; Gonzalez \& Miles, 2000; Jimenez \& Barrilao, 2001, 2003; Maity, \& Sahu, 2019; Muaen, 2016; Shagari, 2014). Furthermore, some studies have performed non empirical analysis of tax administration efficiency (Hunter \& Nelson, 1996; Hyun, Moon, \& An, 2001; Jha \& Sahni, 1997; Jha et al., 1999; Maekawa \& Atoda, 2001; Lewis, 2006). However, corporate taxpayers' perception of tax administration efficiency has not been critically investigated.

To fill this gap, the current study aims at developing and validating relevant and reliable measurement scale for assessing the effectiveness of tax administration efficiency in taxing oil and gas companies operating in the Nigerian oil sector. To this end, this study provides a valid and reliable measurement scale for assessing oil and gas companies' perception of tax administration efficiency which is currently lacking in the existing literature. It may help in bridging the gap. Oil and gas companies were chosen because of the sector's strategic importance in the overall revenue generation in Nigeria (Kyari, 2013). Other scholars also reported that there is paucity of tax research in the Nigerian oil and gas sectors (Oremade, 2010).

\section{Literature Review}

Tax administration literatures virtually emanated from different angle of the world. For instance, tax administration efficiency is considered a significant element in improving the investment climate (Shagari, 2014). The author further reiterated that it increases growth. Tax administration efficiency enables the government to generate more revenue using appropriate tax rates (Rahman, 2009). Tax administration efficiency reduces costs and provides better services to businesses and citizens (OECD, 2011). Abiola and Asiweh (2012) described tax administration as one of the government administrative structures that is entrusted with the responsibilities of tax policy implementation in the country. Moreover, Garde (2004) emphasised that tax administration efficiency involves tax policy administration, modern and efficient tax processes and competent staff.

The literature on tax administration efficiency is scanty despite its importance in influencing taxpayers to pay more tax and in increasing government revenue. Additionally, tax administration function can be improved through the establishment of effective tax laws, policies, staff motivation, taxpayer's 
motivation, strong government commitment and autonomous administration (Joon \& Kim 2011). Moreover, tax administration is considered effective if it has an efficient system that coordinates all the resources to earn revenue for the government (Schlotterbeck, 2017). Frequent self-assessment of tax administration procedures, staff and supporting inputs are vital for the maintenance of efficiency in tax administration (Tennant \& Tennant, 2007). Alm and Duncan (2014) investigated the relative efficiency of tax collection agencies using three steps estimations procedures and data from OECD on internal tax administration efficiency. The authors found that the performance among OECD countries in terms of tax collection is high but lower among the non-OECD countries.

Notwithstanding, Ogbonna (2011) reiterated that inefficient tax administration in Nigeria is due to the poor motivation of taxpayers and tax officials, complex tax laws and policies and weak fiscal autonomy. Lack of sincerity from the tax officials negatively affects tax administration efficiency (Olatunji et al., 2009). Additionally, low staff motivation and dilapidated infrastructure affects the tax administration efficiency (Hassan, 2012).

Consequently, abandoning unnecessary activities, identifying work processes and recording times necessary for each task may be helpful to tax administration in terms of work optimisation and more efficient operation and resources allocation (Pētersone \& Ketners, 2017). Lasheras and Herrera (1991) argued that any successful tax system depends on its administrative policies and their implementation. Accordingly, taxes should not only be considered in terms of tax structure but also from the point of efficacy and efficiency of the tax administration (Villar-Rubio et al., 2017). In many regions, tax administrations are not efficient. For instance, tax administration in Russia is inefficient and expensive hence modernisation of the tax administration system and framework become necessary (Ponomarev et al., 2018). In the Slovak Republic, the customs and tax reforms significantly increase tax administration efficiency (Ali, 2018). On the other hand, the essential structures of tax administration efficiency are strongly established in emerging Europe. However, an assessment of strength, as well as weaknesses of tax administration, are lacking in this region (Crivelli, 2019).

More so, designing tax administration system should be in a such a way to encourage voluntary tax compliance, reduce fraud, reverse possible misrepresentations of taxpayers return and making sure tax regulations are adhered to (González \& Rubio, 2013). From the foregoing discussions, it is worth noting that tax administration efficiency is very significant in nation- 
building as it promotes revenue generation and improves the investment climate. For tax system to be efficient, each tax structure must be designed to reduce evasion (Yusuf \& O'Connell, 2012). Inefficient tax system reduces government revenue, chase away investors, encourage tax evasion and avoidance. Hence, the need for efficient tax administration around the globe for effective revenue generation taking into cognisance of taxpayer's confidence and voluntary compliance.

It is important to highlight the relevant measures adapted to determine tax administration efficiency in this study. For instance, the first item (question) asked was related to the influence of well-trained staff in efficient tax administration. Consequently, it is essential to understand that welltrained staff leads to high productivity in an organisation (Hassan, 2012). Hence, where tax authorities have well-trained staff the expectation will be an increase in tax administration efficiency. The second item asked was related to the adequate infrastructure for efficient tax administration. The question aims at ascertaining whether the taxpayers are fully aware of any available infrastructures put in place by the tax authorities which can help in efficient tax administration. Under normal circumstances, once there is adequate infrastructure, the expectation would be an increase in productivity (Olatunji et al., 2009). Therefore, good infrastructure can lead to efficient tax administration. The third item asked was on the increase of revenue due to the efficient tax administration. It was previously reported that efficient tax administration lead to the increase in government revenue (Rahman, 2009). While the last item asked dealt with the efficiency of the tax collection process. Alm and Duncan (2014) argued that for tax administration to be efficient, there must be an effective tax collection process.

\section{Pools of Items Generation}

Having defined the concept of tax administration, the next stage in the process is to generate a set of items that fully represent the conceptual domain of the construct (Mackenzie et al., 2011). The items are adapted from Shagari (2014), Muaen (2016) and Alharethi (2018). They focus on tax officials in the case of Shagari and Muaen and individual taxpayers in the case of Alharethi. However, the current study adapts the items to investigate the tax administration efficiency among operators in the oil and gas sectors in Nigeria. The measurements as used previously were reported to be valid and reliable with Cronbach alpha of $0.597,0.858$ and 0.795 for Shagari, Muaen and Alharethi (2018), respectively in measuring tax administration efficiency. Table 1 depicts the original and modified item pools. 


\section{Table 1}

\section{Original and Modified Items $P$}

\begin{tabular}{|c|c|c|c|c|}
\hline Authors & Measurements & $\begin{array}{l}\text { Target } \\
\text { respondents }\end{array}$ & Modified measures & $\begin{array}{l}\text { Target } \\
\text { respondent }\end{array}$ \\
\hline \multirow[t]{4}{*}{$\begin{array}{l}\text { Shagari } \\
(2014)\end{array}$} & $\begin{array}{l}\text { My organisation has well- } \\
\text { trained staff for efficient } \\
\text { tax administration. }\end{array}$ & Tax officials & $\begin{array}{l}\text { Tax authority has } \\
\text { well trained and } \\
\text { experienced staff } \\
\text { for efficient tax } \\
\text { administrations. }\end{array}$ & $\begin{array}{l}\text { Oil and gas } \\
\text { companies }\end{array}$ \\
\hline & $\begin{array}{l}\text { My organisation has } \\
\text { adequate infrastructures for } \\
\text { efficient tax administration. }\end{array}$ & & $\begin{array}{l}\text { Tax authority } \\
\text { has adequate } \\
\text { infrastructure } \\
\text { for efficient tax } \\
\text { administration. }\end{array}$ & \\
\hline & $\begin{array}{l}\text { Income generated from } \\
\text { tax revenue by my } \\
\text { organisation has been } \\
\text { impressive due to efficient } \\
\text { tax administration. }\end{array}$ & & $\begin{array}{l}\text { The tax authority } \\
\text { can generate more } \\
\text { revenue from } \\
\text { taxpayers, due to } \\
\text { their, impressive } \\
\text { and efficient tax } \\
\text { administration } \\
\text { approach. }\end{array}$ & \\
\hline & $\begin{array}{l}\text { In my view, our tax system } \\
\text { has an efficient collection } \\
\text { process. }\end{array}$ & & $\begin{array}{l}\text { Tax authority has } \\
\text { an efficient tax } \\
\text { administration } \\
\text { process }\end{array}$ & \\
\hline \multirow[t]{3}{*}{$\begin{array}{l}\text { Muaen } \\
(2016)\end{array}$} & $\begin{array}{l}\text { My organisation has well- } \\
\text { trained staff for efficient } \\
\text { tax administration. } \\
\text { My organisation has } \\
\text { adequate infrastructure for } \\
\text { efficient tax administration. }\end{array}$ & Tax officials & & \\
\hline & $\begin{array}{l}\text { Income generated from } \\
\text { tax revenue by my } \\
\text { organisation has been } \\
\text { impressive due to efficient } \\
\text { tax administration. }\end{array}$ & & & \\
\hline & $\begin{array}{l}\text { In my view, our tax } \\
\text { system has an efficient tax } \\
\text { collection process }\end{array}$ & & & \\
\hline \multirow[t]{4}{*}{$\begin{array}{l}\text { Alharethi, } \\
(2018)\end{array}$} & $\begin{array}{l}\text { Income tax collection is } \\
\text { efficiently administered. }\end{array}$ & $\begin{array}{l}\text { Individual } \\
\text { taxpayers. }\end{array}$ & & \\
\hline & $\begin{array}{l}\text { Tax administration in } \\
\text { Hadhramout is efficient. }\end{array}$ & & & \\
\hline & $\begin{array}{l}\text { Tax system and tax } \\
\text { administration in Yemen } \\
\text { are efficient. }\end{array}$ & & & \\
\hline & $\begin{array}{l}\text { Tax administration in } \\
\text { Yemen is positively } \\
\text { efficient, simple and } \\
\text { effective. }\end{array}$ & & & \\
\hline
\end{tabular}


The researchers modified the questions to come up with the items that can measure the construct under investigation. This approach is in line with the work of Mohammad's (2013) and Manaf et al.'s (2016). As indicated in Table 1, the total of four items were pooled out as potential items to measure the quality of tax administration efficiency. The three studies above were selected due to the zero availability of measures from other empirical studies on tax administration efficiency. Accordingly, to provide a good understanding of contextual factors, a quantitative study was conducted on 300 local and multination oil and gas companies to validate and determine reliable of the tax administration efficiency instruments.

\section{Research Methodology}

\section{Stage One Content Validity}

At this stage, the four items adapted were assessed using the content validity procedure as recommended by Engström et al. (2018). The author recommends that expert evaluation and review of content validity of the item pools should be conducted by individuals with solid knowledge and vast experience on the constructs under investigation as well as specialists on scale construction. This would assist in evaluating whether each item in the questionnaire is vital and suitable to measure the construct (Saunders et al., 2011). Initially, we designed a questionnaire with five-point Likert-type scale to measure the extent of agreement on the tax administration efficiency among oil and gas taxpayers.

The questionnaire was issued and sent to eight experts who had investigated oil and gas fiscal regimes, oil and gas operations and oil and gas tax filling. The experts were selected among professionals in the industry and academia who have published in their fields as recommended by Rubio et al. (2003). The number of experts were within the threshold of two to twenty as recommended by experts (Gable \& Wolf, 1993). Essentially, three checks are expected from the expert; clarity and conciseness of the items and suggestion of additional items which may be relevant but not included in the items pool and to comment on the clarity of the items and appropriate measurements. After receiving their observations and comments, varies changes were made such as the wordings and the selection of 5-Likert scale was concluded based on the comments received.

\section{Stage Two Pilot Study}

At this phase, a pilot study was conducted to further ensure the validity and reliability of the instruments (Creswell, 2012) before the final distribution 
of the questionnaire to the target respondents. According to Hulley (2001), a pilot study is an initial investigation conducted by a researcher which is aimed at assessing the viability, duration as well as the cost expected to be incurred to estimate a suitable sampling size for the study and also to improve the format of the study before undertaking the main research. Also, Altman et al. (2006) emphasised the significant role of the pilot test. He noted that a pilot study is very vital for a researcher to conduct because it may show the imperfections of the structure and design of the study. It may also show errors in the questions to be asked, the metrics used for measurement and the instructions. Thus, this process should be undertaken before eventually engaging in the main research project.

Therefore, in line with this statement and as advocated by Hair et al. (2010) that there should be at least 50 or more responses before performing exploratory factor analysis, a total of 80 copies of the questionnaire were distributed to 80 local and multinational oil and gas companies. To avoid sample selection bias and sample specification error, Heckman (1979) reiterated that one should avoid self-sample selection by individuals and sample selection by analysts or data processors. Additionally, Berk (1983) emphasised that non-random sample selection causes risk of sample selection bias. Based on these assertions and to avoid sample selection bias and error, the current study utilised simple random sampling for the pilot study. Approximately, four items were used for the pilot test which was initially modified based on experts advise. As highlighted earlier, we used five-point Likert scale which ranges from 1 , which is the lowest score, to 5, which is the highest score. This is in line with Hinkin et al.'s study (1997). Based on the simple random sampling and the help from our research assistants, we were able to be retrieve 53 fully completed questionnaires at a response rate of 66.57 percent. For a scale to be considered reliable, the scores must pass some threshold (De vellis, 1991). The most commonly used reliability indicator is internal consistency (Pallant, 2011). Nunnally (1978) categorically stated that the values of items to overall total correlation greater than 0.30 should be considered.

Table 2

Reliability and Validity Analysis of the Instruments (Pilot stud)

\begin{tabular}{lcc}
\hline Variable & Number of items & Cronbach's alpha \\
\hline Tax administration efficiency & 4 & 0.825 \\
\hline
\end{tabular}


The Cronbach alpha of 0.825 is considered strong based on Hair et al.'s (2010) recommendation and this indicates how valid and reliable the items were in measuring the construct. Hence, the Cronbach alpha is above the cut-off point.

\section{Stage Three Final Stage}

At this phase, a survey was conducted to generate the required data. SPSS version 25 and PLS-SEM 3.8 were used in the analysis. .Final questionnaires were distributed among 300 local and multinational oil companies in Nigeria. A total of 189 questionnaires was retrieved (63\%), out of which five were excluded due to the missing data, outliers or absence of variation in response, thereby reducing valid sample size to 184 respondents. Simple random sampling was used in choosing the sample size of the current study. This is because the simple random sampling was originally used in research to support the analysis of a data set or to estimate the parameters of interest (Olken \& Rotem, 1986). The authors further stress that some of the reason for selecting simple random sampling in a study could be that the entire population of the study must be known. In line with this assertion, the current study obtained full address of both local and multinational oil companies from Federal Inland Revenue Service (FIRS), which is one of the key regulatory bodies in the Nigerian oil and gas industries. The population was determined through consultation with the FIRS and this serve as a basis for applying simple random sampling. Although simple random sampling does not guarantee error-free sampling, the error is reduced significantly in a larger sample (Linder, Murphy, \& Briers, 2001).

The population of the study is about 300 oil and gas companies comprising both local and international companies. These companies operate in a kind of incorporated joint ventures and also serve taxable units. As mentioned earlier, the name and addresses of these companies were obtained from FIRS. To avoid sample selection bias, the questionnaires were delivered to the addresses of all these companies that served as the population. This implied that all members of the population were given an equal chance of being selected. After a series of follow-ups, a total of 189 questionnaires were received (representing $63 \%$ of the population). This serves as the final sample which was randomly obtained from the population since all respondnets were given the equal chance of participation in the survey. Exploratory Factor Analysis (EFA) and Confirmatory Factor Analysis (CFA) were conducted since the initial items were scrutinised by the tax officials and individual taxpayers. The next stage was EFA and CFA to explore the measurements in oil and gas industries and confirm the internal consistency reliability among 
oil and gas companies using confirmatory factor analysis (Johari et al., 2011; Thien et al., 2014; Worthington \& Whittaker, 2006).

Therefore, in this stage, EFA is desirable to understand to what extent each factor is explained by the underlying items. To achieve this objective, the principal component analysis and varimax rotation was used. The CFA, Internal consistency reliability, convergence validity of the items were conducted. The internal consistency measures the degree to which items measuring the construct relate to one another in the given structural model. To this end, three statistical measures were carried out to evaluate the internal consistency reliability of the environmental regulation items: (i) Cronbach alpha (ii) Indicator reliability and (iii) Composite reliability. The threshold point for indicator reliability is 0.7 and above (Hair et al., 2010), the Cronbach alpha is 0.7 and above (Nunnally, 1978) and the composite reliability is 0.7 and above (Hair et al., 2010).

\section{Data Analysis}

The objective of the current study is to provide a valid and reliable measurement scale on the tax administration efficiency from oil and gas companies which is currently lacking in the existing literature. The analysis begins with EFA and CFA to ensure a robust assessment of the construct unidimensionality as suggested by Anderson and Gerbing (1988). The SPSS version 25 and PLS-SEM 3.8 were used in the analysis. The summary of the EFA is presented in Table 3.

Table 3

Exploratory Factor Analysis

\begin{tabular}{|c|c|c|c|}
\hline Items & & Factor 1 & Communalities \\
\hline TAE1 & & 0.769 & 0.907 \\
\hline TAE2 & & 0.701 & 0.877 \\
\hline TAE3 & & 0.929 & 0.994 \\
\hline TAE4 & & 0.923 & 0.994 \\
\hline Total Eigenvalues & 2.785 & & \\
\hline \multicolumn{4}{|c|}{ Variance Explained 69.628} \\
\hline \multicolumn{4}{|c|}{ Total Variance Explained 87.909} \\
\hline KMO & 0.672 & & \\
\hline Sig. & 0.000 & & \\
\hline
\end{tabular}


Table 3 presents the exploratory factor analysis on items under investigation. Furthermore, the screen tests were conducted and two factors were eventually extracted based on the Eigenvalues above 1. For factor 1, the Eigenvalue was 7.12 while factor 2 had the value of 0.9 . Following this result it can be understood that the only factor 1 is substantial and the items which fall under factor 1 conform to TAE.

The next analysis was the Confirmatory Factor Analysis (CFA). The Cronbach's $\alpha$ of the tax administration efficiency items were investigated for internal consistency and reliability of the items. Table 4 presents the indicator reliability; Cronbach alpha, Composite Reliability (CR) and Average Variance Extracted (AVE) which serve as the measure of convergent validity of the tax administration efficiency items.

Table 4

Confirmatory Factor Analysis

\begin{tabular}{lcccc}
\hline Items & TAE1 & TAE2 & TAE3 & TAE4 \\
\hline Indicators & 0.806 & 0.730 & 0.894 & 0.888 \\
Cronbach & 0.849 & & & \\
C R & 0.851 & & & \\
A V E & 0.692 & & & \\
\hline
\end{tabular}

As shown in the table above, items loadings, Cronbach alpha, composite reliability and average variance explained as measures of convergent validity were conducted to support the EFA and to further confirm the reliability and validity of the items. Table 4 presents the confirmatory factor analysis result which confirm the reliability and validity of the items to the construct. The indicators loading values are all above the threshold values of $>0.7$ (Hair et al., 2014). This confirms how the items are highly loaded towards explaining the construct. The Cronbach and composite reliability which are the most commonly used criteria for assessing reliability of an items to the main construct, have both scored above the threshold values of $>0.7$ (Hair et al., 2014). The average variance which explains the result is the most used criterion in assessing convergent validity, had a value above the recommended threshold of $>0.5$ (Hair et al., 2016). This indicates how the items converged together in explaining TAE. 
Table 5

Final Valid and Reliable Items for Measuring the Effectiveness of Tax Administration Efficiency on Oil and Gas Companies.

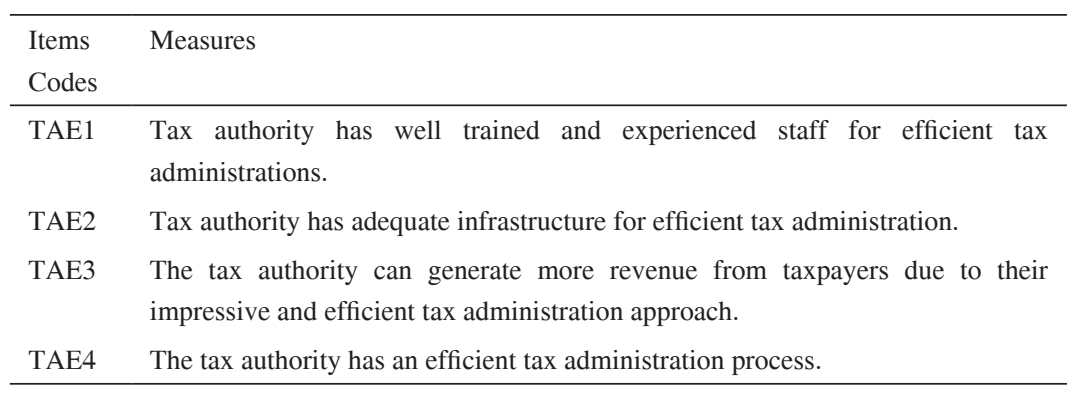

\section{Discussion}

As depicted in Table 2, EFA and screen test were carried out and three factors were eventually extracted. However, only one factor was selected based on the Eigenvalue of above 1. Under the second factor, all loadings were below the significant level of 0.5 (Kaiser ,(970\& Kaiser, 1974) while in Factor 1, all items were significant and loaded above 0.5 with 69.628 per cent variance extracted. Additionally, for Factor 1 the Eigenvalue is 2.785. Therefore, based on the result, it can be concluded that only Factor 1 is highly significant and conform to the tax administration efficiency concept. Consequently, the factor result indicated that Factor 1 should be retained and the Kaiser-Meyer-Olkin (KMO) test was also conducted to measure the sampling adequacy. The cut-off value of KMO is $\geq 0.6$ (Kaiser,1970 \& Kaiser, 1974), while current study KMO is 0.672 at 0.000 significant level which is considered a good measure of sampling adequacy. On the other hand, as shown in Table 3, CFA was also conducted to ascertain the internal consistency, reliability and validity of the items.

To confirm the reliability and validity of the items, Cronbach alpha analysis was conducted and the Cronbach alpha is 0.849 above the cut-off point of $\geq$ 0.70 (Nunnally, 1978). This shows how reliable the items are in measuring the construct under investigation. Indicator reliability was also conducted; the indicator reliability of each items are $\geq 0.70$ and are above the cut-off point (Hair et al., 2010). Therefore, these items are considered to have attained adequate indicator reliability. More specifically, he composite reliability is 0.851 greater than $\geq 0.70$ (Hair et al., 2011; 2012; 2013) indicating high internal consistency reliability in measuring the tax administration efficiency 
among oil and gas companies. Furthermore, AVE was 0.692 which is above the cut-off point $\geq 0.50$ (Hair et al., 2011; 2012; 2013). This is an indication of how strong the items were in terms of convergent validity. Based on the result of our analysis, the measurement scale of environmental regulation compliance consisting of four items achieve the validity and reliability criteria, thus can be employed in future research studies. Based on the insights from Linder et al (2011), the result of the current study can be generalised and applied in various settings within the oil and gas contexts.

\section{Conclusion and Implications}

The paper presents a valid and reliable measurement scale on the tax administration efficiency among oil and gas companies operating in the Nigerian oil and gas industries. The result of the analysis confirms the validity and internal consistency reliability of the scale. The quest for efficient tax administration is a global phenomenon that draws the attention of various stakeholders across the globe. Inefficient tax administration system mostly affects the developing countries because of the multiple political, social and extreme economic inequality. Therefore, efficient tax administration is a crucial area of policymaking in the developing countries. Achieving an efficient tax administration system requires rigorous and frequent tax policy review and implementation to cater for modern tax administration challenges. Policymakers should consider the view of other stakeholders when introducing new tax policies or strengthening existing one.

This is necessary to avoid negative impacts of policy implementation on social, political and economic development of a nation. One of the negative effects of tax policy implementation is creating tax havens which gives room for some individual or companies to relocate their business activities to a country with more friendlier tax policies. In most developing countries, companies pay a significantly higher percentage tax higher than the selfemployed. Therefore, companies might be interested in voicing out their perceptions on whether the existing tax administration process is efficient or not. This can be useful for policymakers to make necessary amendments on their tax policies to avoid encouraging tax haven countries which may have both social, economic and political effect in the long run.

The study fills the gap through validating reliable and valid measurement scale on oil and gas companies' perceptions of tax administration efficiency. Methodologically, prior studies used SPSS and AMOS for confirmatory factor analysis, for instance, Brown and Ki (2013), Manaf et al. (2015), Mas'ud et al. (2017), Adamu and Muhammad (2019) while the current study used 
both SPSS and PLS for confirmatory factor analysis. Precisely, the adapted measurement scale fulfilled the requirements of internal consistency using indicator loadings, Cronbach alpha and composite reliability and convergent validity using AVE. Therefore, this study contributes methodologically and provide measures for application in future studies using different samples. The practical contributions of the study are threefold. Firstly, the validated scale presented in Table 5 can serve as a checklist for oil and gas producing countries while assessing tax administration efficiency or otherwise of their tax administrators. Secondly, the validated scale can be used to assess the perception of oil and gas companies with regards to tax administration efficiency in terms of whether the existing tax policies are efficient or not. Lastly, it can also be used to assess the role of regulatory bodies in assessing the effectiveness and efficiency of the existing tax system while dealing with multinational and local oil companies. Eventually, the scale can assist policymakers across the globe to adapt in investment decision making, particularly regarding existing tax policies, because good tax policies attract investment. From the result, it is obvious that the study provides a reliable scale to assist policymakers across the globe to come up with robust tax policies that can encourage tax administration efficiency.

The measurements can be adopted or adapted by other researchers to suit different industries. Researchers can also use the scale as independent variable, moderator or mediator to investigate the effect and consequences of tax administration policies which can help policymakers in forming robust and more friendlier tax policies. The valid and reliable measures developed in the current study will assist potential researchers in this area to replicate this study in other countries to compare the results. Future researchers on tax administration efficiency should expand the scale by adding other items to fully represent their conceptual and contextual needs. Moreover, this study is a significant step towards making available a valid and reliable scale on tax administration efficiency to assist researchers, policymakers and other stakeholders in this crucial area and to help in providing more insights on whether the existing tax administration policies affects their performance. It can also be useful for policymakers to re-strategise and come up with new policies to attract more investment and improve government revenues.

The generalisation of the result of this study within the context of the oil and gas industry can be justified with four reasons. First, the measures of tax administration efficiency utilised in the study were obtained from studies conducted in reputable universities with specialties in petroleum-related courses. Second, the measures were successfully screened by a pool of eight experts who have experience in oil and gas activities. Third, the sample used in the study serves as a good representative of the population, since all 
the members of the population were given equal chance of being selected. Lastly, the measures were subjected to reliability and validity evaluations which confirmed that they are valid and reliable and can be applied in future research. However, considering the nature and source of the items, the nature of the experts, the scope of the sample, the generalisation of the results of this study may be limited to the oil and gas industries. This implies that further validity and reliability need to be established in other mining sectors such as gold, diamond and other extractive natural resources.

The main limitation of the current study might be that the it focusses on the nonrenewable energy sector. Future research may focus on other mining sectors. SPSS and PLS were used in the current study hence other statistical tools such as the Analysis of Moment Structures (AMOS) can be used in confirming the reliability and validity of the instruments by future researchers.

\section{Acknowledgement}

This research received no specific grant from any funding agency.

\section{References}

Abiola, J., \& Asiweh, M. (2012). Impact of tax administration on government revenue in a developing economy-a case study of Nigeria. International Journal of Business and Social Science, 3(8). 99-113.

Dobrovič, J., Gombár, M., \& Ali, T. V. (2018). Forms of managing the efficiency of tax administration in Slovak Republic. Journal of International Studies, 11(2), 304314. https://doi:10.14254/20718330.2018/11-2/20

Alm, J., \& Duncan, D. (2014). Estimating tax agency efficiency. Public Budgeting \& Finance, 34(3), 92-110.

Altman, D., Burton, N., Cuthill, I., Festing, M., Hutton, J., \& Playle, L. (2006). Why do a pilot study? National Centre for Replacement, Refinement and Reduction of Animal in Research. http://www.nc3rs. org.uk/downloaddoc. .asp? $\mathrm{id}=400$

Anderson, J. C., \& Gerbing, D. W. (1988). Structural equation modelling in practice: A review and recommended two-step approach. Psychological Bulletin, 103(3), 411-423.

Aziz, S. A., \& Al_Harethi, A. R. S. (2018). Factors determining tax administration efficiency in Hadhramout. Yemen: Perception from Individual Taxpayers. 
Bahtiar, M. (2013). The structural relationships between corporate culture, ICT diffusion innovation, corporate leadership, corporate communication management (CCM) activities and organisational performance (e-theses online service). https://ethos.bl.uk/ OrderDetails.do?uin=uk.bl.ethos.577889

Baurer, L. I. (2005). Tax administrations and small and medium enterprises (SME) in developing countries. World Bank Group. http://documents.worldbank.org/curated/en/711511468779448847/ pdf/391100Taxadmin01PUBLIC1.pdf

Berk, R. A. (1983). An introduction to sample selection bias in sociological data. American Sociological Review, 386-398.

Creswell, J. W. (2012). Collecting qualitative data, educational research: Planning, conducting and evaluating quantitative and qualitative research (pp. 204-235). Upper Saddle River, NJ: Pearson.

Crivelli, E. (2019). A basic tool to assess tax administration strength in emerging Europe. Economics of Transition and Institutional Change, 27(2), 425-446.

DeVellis, R. F. (1991). Applied social research methods series. In L, Brickman., \& D. J. Rog. (Eds), Scale development: Theory and applications. Thousand Oaks: Sage.

Dobrovič, J., Gombár, M., \& Ali Taha, V. (2018). Forms of managing the efficiency of tax administration in Slovak Republic. Journal of International Studies, 11(2), 304-314.

Engström, M. S., Leksell, J., Johansson, U. B., Eeg-Olofsson, K., Borg, S., Palaszewski, B., \& Gudbjörnsdottir, S. (2018). A diseasespecific questionnaire for measuring patient-reported outcomes and experiences in the Swedish national diabetes register: Development and evaluation of content validity, face validity, and test-retest reliability. Patient Education and Counseling, 101(1), 139-146.

Esteller, A. (2003). The efficient administration of assigned taxes: An explanatory analysis. Papeles de Economía Española, 95, 320-334.

Gable, R. K., \& Wolf, M. B. (1993). Instrument development in the affective domain: Measuring attitudes and values in corporate and school setting. New York: Kluwer Academic Publisher.

Garde, M. P. (2004). A model for tax administration reform. Business focus bulletin. https://www.dlsu.edu.ph/wp-content/uploads/pdf/vcri/cbrd/ bus_focus/model_for_tax_admin_reform.pdf

González, P. E. B., \& Rubio, E. V. (2013). The efficiency of the regional management centres of the tax administration in Spain. Journal of US-China Public Administration, 10(1), 49-56.

González, X. M., \& Miles, D. (2000). Efficiency in the tax inspectorate. Revista de Economía Aplicada, 24(3), 203-219. 
Gurama, Z., \& Mansor, M. (2015). Tax administration problems and prospect: A case of Gombe state. International Journal of Arts and Commerce, 4(4), 187-196

Hair, J. F., Black, W., Babin. B. J., \& Anderson, R. (2010). Multivariate data analysis. New Jersey: Pearson Prentice Hall.

Hassan, A. G. D. (2012). Tax administration in Kano state: Problems and prospects. International Journal of Arts and Commerce, 1(3),1-6.

Heckman, J. J. (1979). Sample selection bias as a specification error. Econometrica: Journal of the Econometric Society, 153-161.

Hinkin, T. R., Tracey, J. B., \& Enz, C.A. (1997). Scale construction: Developing reliable and valid measurement instruments. Journal of Hospitality and Tourism Research, 21(1), 100-120.

Hulley, S. B., Cummings, T. B., Browner, W. S., Cummings, S. R., Hulley, D. G., \& Hearst, N. (2001). Designing clinical research: An epidemiological approach. Philadelphia: Lippincott, Williams \& Wilkins.

Hunter, W. J., \& Nelson, M. A. (1996). An IRS production function. National Tax Journal, 49(1), 105-115.

Houston, J., \& Tran, A. (2001). A survey of tax evasion using the randomized response technique. In Advances in taxation (pp. 69-94). Emerald Group Publishing.

Hyun, J. K., Moon, CH. G., \& An, CH. B. (2001). Production analysis of tax administration with multiple outputs: The case of Korea. Proceedings from 57th Congress of the International Institute of Public Finance. Linz, Austria.

Jha, R., \& Sahni, B. S. (1997). Tax efficiency and productivity analysis: The case of Canadian fiscal federalism. Public Finance/Finances Publiques, 52(2), 186-197.

Jha, R., Mohanty, M. S., Chatterjee, S., \& Chitkara, P. (1999). Tax efficiency in selected Indian states. Empirical Economics, 24, 641-654.

Jiménez, J. D., \& Barrilao, P. E. (2001). An approach to the efficient management of the state agency of tax administration. Papeles de Economía Española, 87, 221-228.

Jiménez, J. D., \& Barrilao, P. E. (2003). Tax administration in Spain. A management analysis through income and expenditure. Working Paper No. 175/2003. Foundation Confederate Savings for Economic and Social Research.

Joon, K. K., \& Kim, K. S. (2011). Tax administration reform in Korea and its implications. World Bank and KDI School Conference on Fiscal Policy and Management on 14-18 November 2011.

Kaiser, H. F. (1970). A second generation little jiffy. Psychometrika, 35, 401-415.

Kaiser, H. F. (1974). An index of factorial simplicity. Psychometrika, 39, 31-36. 
Kyari, A. K., (2013). A theoretical and empirical investigation into the design and implementation of an appropriate tax regime: an evaluation of Nigeria's petroleum taxation arrangements (Unpublished doctoral dissertation). Robert Gordon University UK).

Lasheras, M. A., \& Herrera, C. (1991). Administración tributaria y sistema fiscal. Un análisis comparado. Papeles de Trabajo, 14. Instituto de Estudios Fiscales.

Lewis, B. D. (2006). Local government taxation: An analysis of administrative cost efficiency. Bulletin of Indonesian Economic Studies, 42, 213233.

Lindner, J. R., Murphy, T. H., \& Briers, G. E. (2001). Handling nonresponse in social science research. Journal of Agricultural Education, 42(4), 43-53.

Maekawa, S., \& Atoda, N. (2001). Technical inefficiency in Japanese tax administration. Proceedings from 57th Congress of the International Institute of Public Finance. Linz, Austria.

Manaf, N. A. A., Mas' ud, A., Ishak, Z., Saad, N., \& Russell, A. (2016). Towards establishing a scale for assessing the attractiveness of petroleum fiscal regimes-Evidence from Malaysia. Energy policy, 88, 253-261.

Maity, S., \& Sahu, T. N. (2019). Is the efficiency of banks degenerating due to the mounting of non-performing assets? An empirical investigation using DEA. Malaysian Management Journal,23, 65-86.

Muaen, M. A. (2016). Determinants of tax administration efficiency in Libya (Unpublished doctoral dissertation) Universiti Utara Malaysia. http://etd.uum.edu.my/6044/2/s815265_02.pdf

Nkundabanyanga, S. K., Mvura, P., Nyamuyonjo, D., Opiso, J., \& Nakabuye, Z. (2017). Tax compliance in a developing country: Understanding taxpayers' compliance decision by their perceptions. Journal of Economic Studies, 44(6), 931-957.

Nunnally, J. C. (1978). Psychometric theory. NewYork: McGraw-Hill.

Nyabwengi, L. M., \& K'Akumu, O. A. (2019). An evaluation of property tax base in Nairobi city. Journal of Financial Management of Property and Construction,24(2), 184-199.

OECD (2011). Efficiency of tax administrations. In government at a glance 2011, OECD Publishing. http://dx.doi.org/10.1787/gov_glance2011-64-en

Ogbonna, G. N. (2011). Burning issues and challenges of the Nigerian tax systems with analytical emphasis on petroleum profit tax. International Journal of Accounting, Finance and Economics Perspectives, 1, 85-87. 
Olatunji, O. C., Taiwo, O. A., \& Adewole, J. O. (2009). A review generation in Nigeria local government: A case study of Ekiti state. International Business Management, 3(3), 54-60.

Olken, F., \& Rotem, D. (1986). Simple random sampling from relational databases.https://escholarship.org/content/qt9704f3dr/qt9704f3dr. pdf

Oremade, B. T. (2010). Perception of petroleum profits tax compliance in Nigeria (Unpublished doctoral dissertation). Bournemouth University. Retrieved fromhttp://eprints.bournemouth.ac.uk/17520/1/ Tunde_COMPLETED_THESIS_NOVEMBER_2010.pdf

Pallant, J. (2011). SPSS survival manual: A step by step guide to data analysis using SPSS. Crows Nest: Allen \& Unwin.

Pētersone, M., \& Ketners, K. (2017). Improvement of customs and tax administration ICT system performance. Research for Rural Development, 2. https://doi:10.22616/rrd.23.2017.077

Ponomarev, A. I., Ponomareva, A. M., Ponomarev, M. A., \& Toporov, I. V. (2018). Theoretical and methodological grounds for the modernization of the tax administration system. European Research Studies, 21, 544.

Rahman, A. (2009). Investment climate in practice: Tackling corruption through tax administration reform. World Bank. Retrieved from: https://openknowledge.worldbank.org/bitstream/handle/10986/1056 4/483120BRI0FIAS10Box338894B01PUBLIC1.pdf?sequence $=1$

Rubio, D. M., Berg-Weger, M., Tebb, S. S., Lee, E. S., \& Rauch, S. (2003). Objectifying content validity: Conducting a content validity study in social work research. Social Work Research, 27(2), 94-104.

Saunders, M., Lewis, P., \& Thornhill, A. (2011). Research methods for business students (5th ed.). Harlow, Essex: Pearson Education.

Schlotterbeck, S. (2017). Tax administration reforms in the Caribbean: Challenges, achievements, and next steps. International Monetary Fund.

Shagari, S. L. (2014). Determinants of tax administration efficiency: A study of Bauchi State, Nigeria (Unpublished doctoral dissertation). Universiti Utara Malaysia. http://etd.uum.edu.my/4127/2/s814479_ abstract.pdf

Tennant, S., \& Tennant, D. (2007). The efficiency of tax administration in Jamaica: An introspective assessment. Social and Economic Studies, 71-100.

Umar, M. A., \& Masud, A. (2020). Why information technology is constrained in tackling tax noncompliance in developing countries: Nigerian tax administrators' perspectives. Accounting Research Journal, 33(2), 307-322. https://doi.org/10.1108/ARJ-11-2018-0United 
Nations (2000). Improving tax administration in Sub-Saharan Africa: The potential of revenue agencies and electronic service delivery. http:// unpan1.un.org/intradoc/groups/public/documents/UN/.

Villar-Rubio, E., BarrilaoGonzález, P. E., \& Delgado-Alaminos, J. (2017). Relative efficiency within a tax administration: The effects of result improvement. Revista Finanzas y Politica Económica, 9(1), 135-149.

Worthington, R. L., \& Whittaker, T. A. (2006). Scale development research a content analysis and recommendations for best practices. The Counseling Psychologist, 34, 806- 838.

Yusuf, J. E., \& O'Connell, L. (2012). How effective is the international fuel tax agreement as a multistate tax administration model? A view from the states. Journal of Public Budgeting, Accounting \& Financial Management, 24(4), 535-557. 